\title{
Article
}

\section{Cell Performance of the Membrane Electrode Assembly Based on Sulfonated-FEP/Nafion ${ }^{\circledR}$ Blended Polymer}

\author{
Yuji Oshima, Yukiko Sato, Kazuki Fujii, Naohiro Mitani, Akio Matsuura, Tomoyuki Kakigi, \\ Jingye Li, Masayuki Ito, Akihiro Oshima and Masakazu Washio \\ Advanced Research Institute for Science and Engineering, \\ Waseda University, 3-4-1, Okubo Shinjuku, Tokyo, 169-8555, Japan
}

(Manuscript submitted March 31, 2007; accepted May 25, 2007)

\begin{abstract}
The sulfonated poly(tetrafluoroethylene-co-hexafluoropropylene) (s-FEP) membranes were synthesized by electron beam (EB) induced grafting method and then milled to the powder. The $s$-FEP/Nafion ${ }^{\circledR}$ blended dispersion $(f n)$ was prepared by mixing $s-F E P$ powder with the Nafion ${ }^{\circledR}$ dispersion. The $s-F E P /$ Nafion $^{\circledR}$ blended membrane $(F N)$ was obtained by casting the $f n$ binder into the membrane. The membrane electrode assemblies (MEAs) were fabricated by using the proton exchange membranes ( $F N$ or Nafion $\left.{ }^{\circledR} 112\right)$ and the Pt/C electrodes coated with the binders $(f n$ or Nafion ${ }^{\circledR}$ dispersion). The fuel cell performances of the MEAs were examined. The maximum power density of the MEA using $F N$ membrane and $f n$ binder (particle size of $s-F E P: 48 \pm 17 \mu \mathrm{m}$ ) was about $600 \mathrm{~mW} \mathrm{~cm}^{-2}$. This was higher performance than any other tested MEAs. It is considered that this is because the compatibility at the membrane-binder interfaces is improved and the thermophysical properties of the PEM and the binder are essentially the same due to basically the same material.
\end{abstract}

Key words: fuel cell performance, membrane electrode assembly, sulfonated-FEP/Nafion ${ }^{\circledR}$ blended polymer, binder

\section{Introduction}

The proton exchange membrane fuel cell (PEMFC) is now in the focus as the most promising energy source for the vehicles and other mobile applications.[1,2] In the PEMFC, the proton exchange membrane (PEM) is an important component, which separates the reaction gases and transfers the protons. Nafion ${ }^{\circledR}$ (DuPont de Nemours Ltd.) membrane is the most popular PEM used in PEMFC. However, this material is expensive due to the complex fluorine chemistry involved in the fabrication.[3] Hence, it is necessary to develop the PEM which fills the low cost as well as the required functionality. Radiation induced grafting of functional monomers into polymer films and sulfonation was designed as an alternative way to synthesize the PEM with low cost for the PEMFC application.[3-13] The amount of grafting can be controlled by appropriate variation of irradiation and reaction parameters.[5] Thus, the PEM can be developed for a specific application.

Our research group has been developed the partially fluorinated PEMs for PEMFC application by grafting of styrene onto the poly(tetrafluoroethylene-co-hexafluoropropylene) (FEP) films or the crosslinked FEP 
films using radiation grafting method.[12,13] As the result, it succeeded in the development of the high ion exchange capacity (IEC) and high thermostability PEMs. And the fuel cell performances of the membrane electrode assemblies (MEAs) based on the obtained PEMs are higher than those of the MEA based on Nafion ${ }^{\circledR}$.[12] However, at high-temperature e.g. $60^{\circ} \mathrm{C}$ and $80^{\circ} \mathrm{C}$, the MEA based on obtained PEMs showed a less performance than the MEA based on Nafion ${ }^{\circledR}$. The reason may be the delamination at the membrane-electrode interfaces due to their difference of thermophysical properties of the PEMs and $\mathrm{Nafion}^{\circledR}$ dispersion which was used as the binder between the membrane and the electrode. Hence, we focused the developments on the improvement of the interface properties.

This paper describes that the results of fabricated MEAs based on sulfonated-FEP/Nafion ${ }^{\circledR}$ blended membrane. The binder used basically the same material as the membrane to improve the compatibility at the membrane-binder interfaces. The cell performance test and the electrochemical impedance spectroscopy (EIS) of the MEAs were carried out. The MEA based on a Nafion ${ }^{\circledR}$ was also prepared as a reference.

\section{Experimental}

\subsection{Preparation of PEMs and binders}

The poly(tetrafluoroethylene-co-hexafluoropropylene) (FEP) films with a thickness of $25 \mu \mathrm{m}$ and 50 $\mu \mathrm{m}$ were supplied from FLON INDUSTRY CO., LTD. FEP films were irradiated to doses of $15 \mathrm{kGy}$ under nitrogen atmosphere at room temperature $\left(\mathrm{RT} ; 25^{\circ} \mathrm{C}\right)$ by EB accelerator (Curetron ${ }^{\circledR}$, NHV Corp., $200 \mathrm{kV}, 1 \mathrm{~mA}$, $15 \mathrm{kGy}_{\text {pass }^{-1}}$ ). And then FEP films were grafted by styrene at $80^{\circ} \mathrm{C}$ in liquid phase. The grafted films were sulfonated by chlorosulfonic acid in carbontetrachloride solution $(1: 100, \mathrm{vol} / \mathrm{vol})$ at RT for $24 \mathrm{~h}$, and the sulfonated FEP $(s-F E P)$ membranes were obtained, as reported previously.[9-13]

Three kinds of the $s-F E P$ powder with different particle sizes were prepared, and listed in Table 1 . The powder (a) was obtained by milling the $s$-FEP membranes on Speed Rotor Mill equipment (FRITSCH) under $15000 \mathrm{rpm}$ for $10 \mathrm{~min}$. The powder (b) was obtained by pounding the powder (a) in a mortar. The powder (c) was obtained by passing the powder (a) and (b) through a sieve with a hole size of Table 1. The s-FEP powders with different crushing method

\begin{tabular}{lcc}
\hline & Crushing method & Particle size $(\mu \mathrm{m})$ \\
\hline powder (a) & Speed Rotor Mill & $74 \pm 37$ \\
powder (b) & Speed Rotor Mill $\rightarrow$ mortar & $51 \pm 58$ \\
powder (c) & Speed Rotor Mill $\rightarrow$ mortar $\rightarrow$ sieve & $48 \pm 17$ \\
\hline
\end{tabular}
$45 \mu \mathrm{m}$.

The powder (a), Nafion ${ }^{\circledR}$ dispersion and 1-propanol were mixed (the powder (a): $\mathrm{Nafion}^{\circledR}=1: 1, \mathrm{wt} / \mathrm{wt}$ ) and then casted on a clean glass plate at RT. Furthermore, the dried blended membrane was dried in vacuum at 80 ${ }^{\circ} \mathrm{C}$ for $2 \mathrm{~h}$, and the $s-F E P /$ Nafion ${ }^{\circledR}$ blended membrane $(F N)$ was obtained.

The $s-F E P /$ Nafion ${ }^{\circledR}$ blended dispersions $(f n)$ were fabricated by mixing the powder (a), (b) or (c) with Nafion ${ }^{\circledR}$ dispersion $(1: 1, \mathrm{wt} / \mathrm{wt})$, abbreviated as the $f n-a, f n-b, f n-c$ binder.

Nafion ${ }^{\circledR} 112$ membrane was supplied from DuPont de Nemours Ltd., and was used as a reference material. Nafion ${ }^{\circledR}(5 \%)$ dispersion type of DE-521 was purchased from DuPont Fluoroproducts, abbreviated as the Table 2. The composition of the binders used in the cell performance test

\begin{tabular}{|c|c|c|c|c|}
\hline \multirow{2}{*}{ Binder } & \multicolumn{2}{|r|}{$s-F E P$} & \multirow{2}{*}{ Nafion $^{\circledR}$ dispersion $(\mathrm{ml})$} & \multirow{2}{*}{ 1-propanol (ml) } \\
\hline & Weight (mg) & Average particle size $(\mu \mathrm{m})$ & & \\
\hline$f n-a$ & 8.2 & $74 \pm 37$ & $0.178\left(\right.$ Nafion $\left.^{(B)}=8.2 \mathrm{mg}\right)$ & 0.178 \\
\hline$f n-b$ & 8.2 & $51 \pm 58$ & $0.178\left(\right.$ Nafion $\left.^{\circledR}=8.2 \mathrm{mg}\right)$ & 0.178 \\
\hline$n(0.356 \mathrm{ml})$ & - & - & $0.356\left(\mathrm{Nafion}^{\circledR}=16.4 \mathrm{mg}\right)$ & - \\
\hline$f n-c$ & 2.3 & $48 \pm 17$ & $0.050\left(\mathrm{Nafion}^{(\mathbb{8}}=2.3 \mathrm{mg}\right)$ & - \\
\hline$n(0.100 \mathrm{ml})$ & - & - & $0.100\left(\right.$ Nafion $\left.^{\circledR}=4.6 \mathrm{mg}\right)$ & - \\
\hline
\end{tabular}


$n$ binder. The notations and the compositions of the binder are listed in Table 2 .

\subsection{Measurements}

The particle sizes of milled $s$-FEP powder were measured by scanning electron microscope (SEM, S-2500CX, Hitachi Co. Ltd.)

The ion exchange capacity (IEC) values of PEMs were determined by acid-base titration method with the 716 DMS Titrino automatic titrator (Metrohm herisau Co., Ltd.).

Carbon electrodes with $1 \mathrm{mg} \mathrm{cm}^{-2} \mathrm{Pt}(20 \mathrm{wt} . \% \mathrm{Pt} / \mathrm{VXC} 72)$ loaded were purchased from ElectroChem, Inc. The Pt/C electrodes were coated with the binder and then dried at $80{ }^{\circ} \mathrm{C}$ for $2 \mathrm{~h}$. The amount of the coated binder was about $1 \mathrm{mg} \mathrm{cm}^{-2}$ or about $4 \mathrm{mg} \mathrm{cm}^{-2}$. The PEMs were swollen in deionized water for $1 \mathrm{~h}$ and then dried the water on surface. The MEAs were then fabricated by pressing the PEMs and the Pt/C electrodes coated with the binder at $110{ }^{\circ} \mathrm{C}$ under $8 \mathrm{MPa}$ for $3 \mathrm{~min}$. The MEAs were put in JARI standard fuel cell from Hokuto Denko Co. The effective areas of the MEAs were $1 \mathrm{~cm}^{2}$.

The fuel cell tests were performed by HZ-3000 Electrochemical analysis system, Hokuto Denko Co., which consists of $50 \mathrm{~V} / 10$ A power units, automatic polarization system together with a NF5080 Frequency Response Analyzer, from NF Electronic Instruments Co. The hydrogen and oxygen gases were supplied at 0.2 $\mathrm{MPa}$ and the fluxes were fixed at $50 \mathrm{ml} \mathrm{min}^{-1}$. The hydrogen gas was humidified by passing it through a water tank at $25{ }^{\circ} \mathrm{C}$ while the oxygen gas was dry. The cell temperature was $60{ }^{\circ} \mathrm{C}$. The EIS was measured using the 4-electrode frequency response analyzer method, and was taken at a DC current density of $500 \mathrm{~mA} \mathrm{~cm}^{-2}$ with frequency ranging from $100 \mathrm{kHz}$ to $1 \mathrm{~Hz}$.

\section{Results and Discussion}

\subsection{Particle size effect}

Figure 1 shows the SEM photographs of the obtained s-FEP powder. The powder (a) was obtained by milling $s$-FEP membranes with the Speed Rotor Mill equipment. The powder (b) was prepared by pounding the powder (a) in a mortar. The average particle size of the powder (a) and (b) are listed in Table 1. The particle size of the powder (a) was $74 \mu \mathrm{m}$, and the standard deviation of the powder (a) size was $37 \mu \mathrm{m}$. The particle size of the powder (b) was $51 \mu \mathrm{m}$, and the standard deviation of the powder (b) size was $58 \mu \mathrm{m}$. The particle size of the powder (b) was about $20 \mu \mathrm{m}$ smaller than that of the powder (a). However, the standard deviation of powder (b) size was still about $20 \mu \mathrm{m}$ larger than that of powder (a).

The $f n-a$ binder was prepared by mixing the obtained powder (a) with the Nafion ${ }^{\circledR}$ dispersion $(1: 1, \mathrm{wt} / \mathrm{wt})$. And the $f n-b$ binder was prepared by mixing the obtained powder (b) with the Nafion ${ }^{\circledR}$ dispersion $(1: 1$, $w t / w t)$. The MEAs were fabricated by pressing the $\mathrm{Pt} / \mathrm{C}$ electrodes coated with the binder ( $f n-a$ or $f n-b)$ and the $F N$ membrane composed of powder (a) and Nafion ${ }^{\circledR}(1: 1, w t / w t)$.

Figure 2 shows the cell performances of the MEAs with different particle sizes of the binder at the cell temperature of $60{ }^{\circ} \mathrm{C}$. The notations for the MEAs were designated as
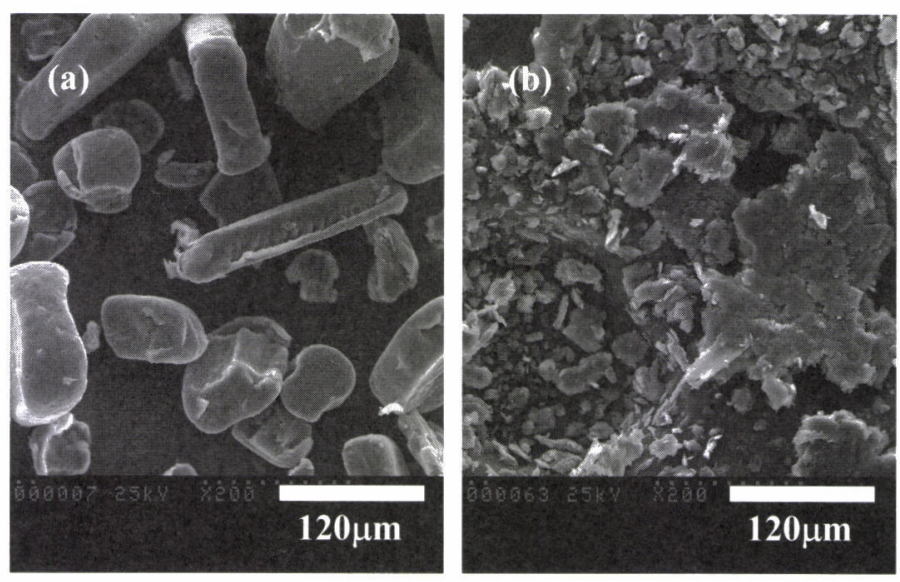

Fig.1. The SEM photographs of the powders with different crushing method: (a) Speed Rotor Mill, (b) Speed Rotor Mill $\rightarrow$ mortar. 
PEM/binder, and showed the combination of the PEMs and the binders. The cell performance of the $F N / f n-b$ was higher than that of the $F N / f n-a$. It is indicated that small particle size shows higher performance than large particle size. It is considered that adhesion property at the membrane-electrode interfaces is improved by smaller particle size.

The power density at the current density of $500 \mathrm{~mA} \mathrm{~cm}$ and maximum power density of the $F N / n(0.356 \mathrm{ml})$ were higher than those of the $F N / f n-a$ and $F N / f n-b$. However, the power density of the $F N / n(0.356 \mathrm{ml})$ was deteriorated compared with those of the $F N / f n-a$ and the $F N / f n-b$ at the high current density region. It may be due to the larger mass transfer resistance of the

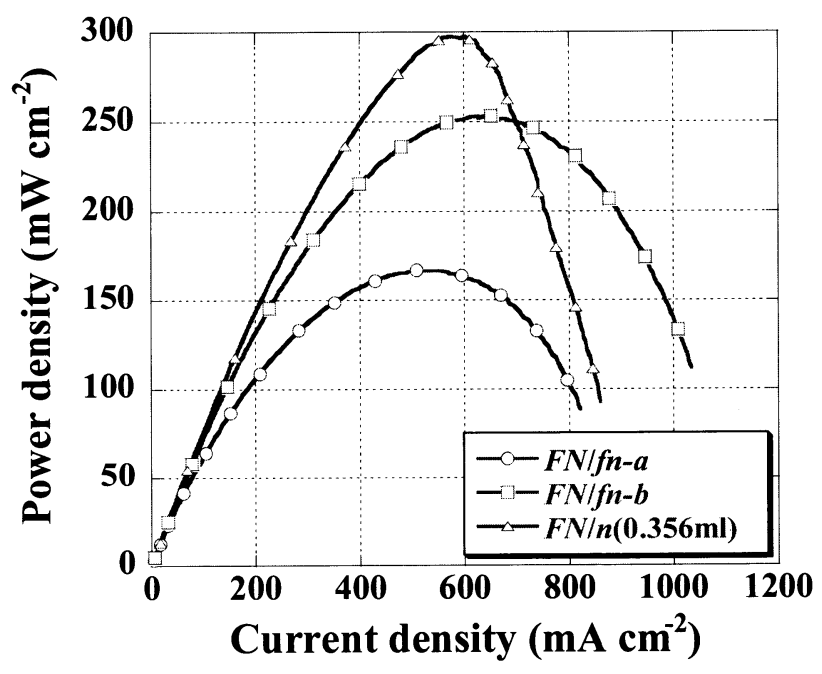

Fig.2. The cell performance data of the MEAs with different particle sizes of the binder: cell temperature: 60 ${ }^{\circ} \mathrm{C}, \mathrm{H}_{2} / \mathrm{O}_{2}$ gas flow: $50 \mathrm{ml} \mathrm{min}^{-1}$, gas pressure: $0.2 \mathrm{MPa}$, $\mathrm{H}_{2}$ humidified at $25^{\circ} \mathrm{C}, \mathrm{O}_{2}$ dry $F N / n(0.356 \mathrm{ml})$ than those of the $F N / f n-a$ and the $F N / f n-b$. Because, drop of the power density at the high current density region should be due to the decreasing of the diffusion process as pointed out in previous paper.[14] It is thought that the large mass transfer resistance for the $n(0.356 \mathrm{ml})$ binder using $\mathrm{Nafion}^{\circledR}$ dispersion is the twice amount compared to the $f n-a$ and the $f n-b$ binder, which is to normalize the weight of electrolyte for the binder.(Table 2) The amount of Nafion ${ }^{\circledR}$ dispersion in the $n(0.356 \mathrm{ml})$ binder was $0.356 \mathrm{ml}$, while the amount of Nafion ${ }^{\circledR}$ dispersion in the $f n-a$ or the $f n-b$ binder was $0.178 \mathrm{ml}$. It may be considered that Nafion ${ }^{\circledR}$ reaches in the $\mathrm{Pt} / \mathrm{C}$ electrode due to the small particle size and the $\mathrm{Pt} / \mathrm{C}$ electrode retains the water easily. Thus, the larger amount of Nafion ${ }^{\circledR}$ dispersion in the binder obtains water at the Pt/C electrode more easily, and then the water at the Pt/C electrode blocks up the diffusion of the gas. The precise experiments are now undergoing.

It was found that smaller particle size showed higher cell performance, but the particle size distributions of the powder (a) and (b) were wide. Hence, by passing the powder (a) and (b) through a sieve (hole size; $45 \mu \mathrm{m}$ ), the powder (c) with smaller particle size and narrower distribution than the powder (a) and (b) was obtained. Figure 3 shows the SEM photograph of the powder (c), and its particle size is listed in Table 1. The particle size of the powder (c) was $48 \mu \mathrm{m}$, and the standard deviation of the powder (c) size was $17 \mu \mathrm{m}$. The $f n-c$ binder was prepared by mixing the powder (c) with the $\mathrm{Nafion}^{\circledR}$ dispersion $(1: 1, \mathrm{wt} / \mathrm{wt})$. And it was found that the mass transfer resistance became large when the amount of the Nafion ${ }^{\circledR}$ dispersion was increased. Hence, the case to use small amount of $\mathrm{Nafion}^{\circledR}$ dispersion was examined. In the section 3.2, the amount of Nafion ${ }^{\circledR}$ dispersion in the $n(0.100 \mathrm{ml})$ binder and the $f n-c$ binder were $0.100 \mathrm{ml}$ and $0.050 \mathrm{ml}$, respectively. And 1-propanol solution was not added to the binder. After the MEA of the $F N / f n-c$ was fabricated, the cell performance of the MEA was examined.

\subsection{Cell performance of the MEAs}

Figure 4 shows the cell performances of the MEAs at the cell temperature of $60{ }^{\circ} \mathrm{C}$. The maximum power densities of the $F N / f n-c, F N / n(0.100 \mathrm{ml}), s-F E P / n(0.100 \mathrm{ml})$, Nafion ${ }^{\circledR} 112 / n(0.100 \mathrm{ml})$ were 592, 452, 359, $398 \mathrm{~mW} \mathrm{~cm}^{-2}$, respectively. The power density at the current density of $500 \mathrm{~mA} \mathrm{~cm}$ and maximum power density of the $F N / f n-c$ were higher than those of the $F N / n(0.100 \mathrm{ml})$. The power density of the $F N / n(0.100 \mathrm{ml})$ was higher 
than that of the $s-F E P / n(0.100 \mathrm{ml})$. The MEAs with the more similar material of the PEMs and the binders showed the higher power densities. It may be considered that the compatibility at the membrane-binder interfaces is improved and the thermophysical properties of the PEM and the binder are essentially the same due to basically the same material. Thus, the power density is increased.

The power density at the current density of $500 \mathrm{~mA} \mathrm{~cm}^{-2}$ and maximum power density of the $F N / f n-c$ were higher than those of the Nafion ${ }^{\circledR} 112 / n(0.100 \mathrm{ml})$, although each of the MEAs used the same material in the PEM and the binder. This may be due to the higher IEC value of the $F N / f n-c$ than the Nafion ${ }^{\circledR} 112 / n(0.100 \mathrm{ml})$.

The EIS of the obtained MEAs was measured at a DC current density of $500 \mathrm{~mA} \mathrm{~cm}^{-2}$. The EIS curves did not exactly show the shape of semicircle, therefore, the equivalent circuit [11]

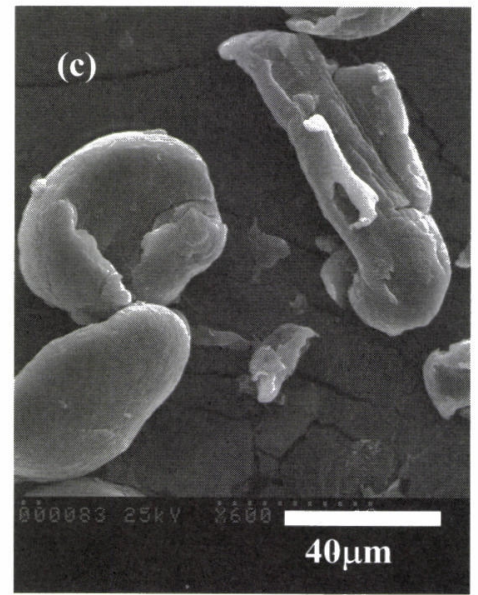

Fig.3. The SEM photograph of the powder (c).

crushing method: Speed Rotor Mill $\rightarrow$ mortar $\rightarrow$ sieve

which expected from semicircle could not use. Hence, in this paper, we referred to the report [3], which was written by Scherer's research group. The intersection of the impedance spectrum with the real axis at the high frequency end yields a measure for the ohmic resistance $\left(R_{\mathrm{ohm}}\right)$ of the MEA, and the charge transfer resistance $\left(R_{\mathrm{ct}}\right)$ is obtained by subtracting the $R_{\text {ohm }}$ value at the intersection of the spectrum with the real axis at the low frequency end. The ionic conductivity (IC) values of the PEMs were calculated by dividing the thickness of the PEMs by the $R_{\text {ohm }}$. The $R_{\text {ohm }}$, the $R_{\text {ct }}$ and the IC values are listed in Table 3 .

The $R_{\mathrm{ohm}}$ and $R_{\mathrm{ct}}$ values of the $F N / f n-c$ were lower than those of the $F N / n(0.100 \mathrm{ml})$. The $R_{\text {ohm }}$ and $R_{\text {ct }}$ values of the $F N / n(0.100 \mathrm{ml})$ were

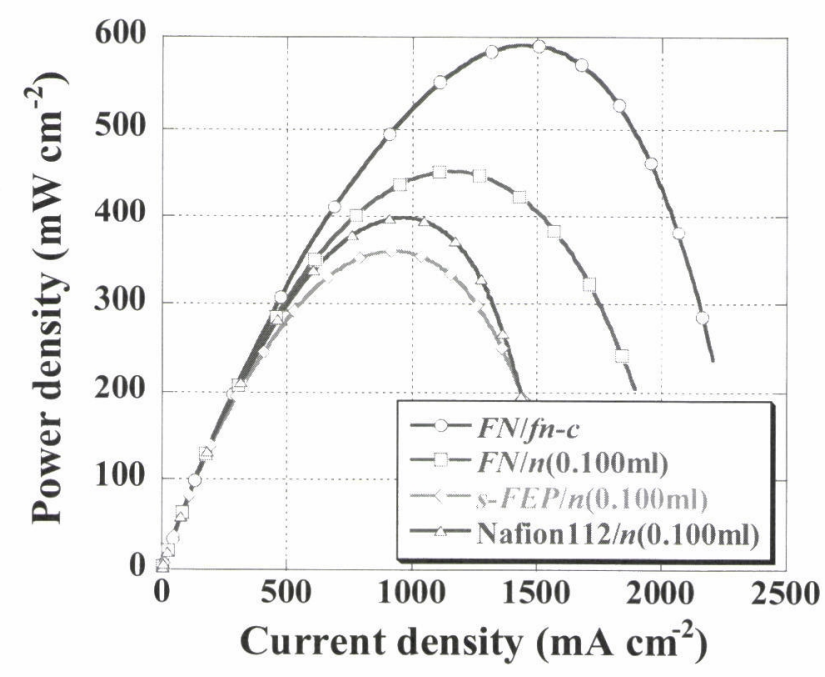

Fig.4. The cell performance data of the MEAs: cell temperature: $60{ }^{\circ} \mathrm{C}, \mathrm{H}_{2} / \mathrm{O}_{2}$ gas flow: $50 \mathrm{ml} \mathrm{min}^{-1}$, gas pressure: $0.2 \mathrm{MPa}, \mathrm{H}_{2}$ humidified at $25^{\circ} \mathrm{C}, \mathrm{O}_{2}$ dry lower than those of the $s-F E P / n(0.100 \mathrm{ml})$. The MEAs with the more similar material of the PEMs and the binders showed the lower $R_{\mathrm{ct}}$ values. On the other hand, the IC values of the MEAs based on synthesized PEMs were almost the same. It may be considered that the improvement of the compatibility at the membrane-binder interfaces due to basically the same material gives the decrease of the $R_{\mathrm{ct}}$ values, and the decrease of the $R_{\mathrm{ct}}$ values gives the improvement of the cell performance.

Table 3. Electrochemical properties of the MEAs at $60^{\circ} \mathrm{C}$

\begin{tabular}{|c|c|c|c|c|c|c|}
\hline \multirow[b]{2}{*}{$\begin{array}{l}\text { MEA } \\
\text { PEM/Binder }\end{array}$} & \multicolumn{2}{|c|}{ Membrane } & \multirow{2}{*}{$\begin{array}{c}\text { Binder } \\
\text { IEC } \\
\left(\text { meq g }^{-1}\right)\end{array}$} & \multirow[b]{2}{*}{$R_{\mathrm{ohm}}\left(\Omega \mathrm{cm}^{2}\right)$} & \multirow{2}{*}{$\begin{array}{c}\text { IC of } \\
\text { membrane } \\
\left(\mathrm{S} \mathrm{cm}^{-1}\right)\end{array}$} & \multirow[b]{2}{*}{$R_{\mathrm{ct}}\left(\Omega \mathrm{cm}^{2}\right)$} \\
\hline & $\begin{array}{c}\text { Thickness* } \\
(\mu \mathrm{m})\end{array}$ & $\begin{array}{c}\text { IEC } \\
\left(\text { meq }^{-1}\right)\end{array}$ & & & & \\
\hline$F N / f n-c$ & 100 & 1.3 & 1.3 & 0.067 & 0.15 & 0.22 \\
\hline$F N / n(0.100 \mathrm{ml})$ & 113 & 1.3 & 0.9 & 0.075 & 0.15 & 0.32 \\
\hline$s-F E P / n(0.100 \mathrm{ml})$ & 100 & 1.9 & 0.9 & 0.070 & 0.14 & 0.41 \\
\hline Nafion $112 / n(0.100 \mathrm{ml})$ & 60 & 0.9 & 0.9 & 0.15 & 0.04 & 0.28 \\
\hline
\end{tabular}

* Measured under swollen states 
The $R_{\mathrm{ct}}$ value of the $F N / f n-c$ was somewhat lower than that of the Nafion ${ }^{\circledR} 112 / n(0.100 \mathrm{ml})$, and the IC value of the $F N / f n-c$ was quite higher than that of the Nafion ${ }^{\circledR} 112 / n(0.100 \mathrm{ml})$. This is an indication that the main reason for higher power density of the $F N / f n-c$ would be the higher IC value as compared with the Nafion ${ }^{\circledR} 112 / n(0.100 \mathrm{ml})$. It might be explained that the IC value of the $F N / f n-c$ is higher than that of the Nafion ${ }^{\circledR} 112 / n(0.100 \mathrm{ml})$ due to the higher IEC value of the $F N / f n-c$. Another explanation might be the manufacture process of the MEAs. In previous research when the MEAs were prepared, the binder was spread on both the PEMs and the Pt/C electrodes.[11] In this paper, however, the binder was not on the PEMs but on the Pt/C electrodes. After the PEMs were swollen in deionized water, the MEAs were fabricated by pressing the PEMs and the $\mathrm{Pt} / \mathrm{C}$ electrodes coated with the binder. Hence, it is considered that the water uptake of the PEMs also affects on the adhesion property at the membrane-electrode interfaces. The synthesized PEMs such as the $F N$ and the $s$-FEP were higher water uptake than the Nafion ${ }^{\circledR} 112$ [13], and the $F N$ and the $s$-FEP were softer membranes than the Nafion ${ }^{\circledR} 112$. Thus, the adhesion property at the membrane-electrode interfaces of the $F N / f n-c$ was improved, and the IC value of the $F N / f n-c$ was higher.

From Figures 2 and 4, the power density of the $F N / n(0.356 \mathrm{ml})$ was lower than that of the $F N / n(0.100 \mathrm{ml})$. The MEA with low Nafion ${ }^{\circledR}$ loadings was poorer performance than that with high loadings. It may be considered that mass transport resistance would become large because the Nafion ${ }^{\circledR}$ dispersion soaked into the $\mathrm{Pt} / \mathrm{C}$ electrode.

\section{Acknowledgement}

The authors acknowledge Dr. M. Motomatsu of DuPont KK. for helpful and valuable discussions of PEMFC. This study was performed by the projects research of RISE, Waseda University, "the manufacturing of high functional fluorinated-polymer materials"; we would like to acknowledge our research group members.

\section{References}

1) G.J.K. Acres, J. Power Sources 100, 60-66 (2001).

2) J. Hall, R. Kerr, J. Cleaner Prod. 11, 459-471 (2003)

3) L. Gubler, N. Prost, S.A. Gürsel, G.G. Scherer, Solid State Ionics 176, 2849-2860 (2005).

4) T.R. Dargaville, G.A. George, D.J.T. Hill, A.K. Whittaker, Prog. Polym. Sci. 28, 1355-1376 (2003).

5) M.M. Nasef, E.A. Hegasy, Prog. Polym. Sci. 29, 499-561 (2004).

6) L. Gubler, S.A. Gürsel, G.G. Scherer, Fuel Cells 5, 317-335 (2005).

7) J.Y. Li, K. Sato, S. Ichizuri, S. Asano, S. Ikeda, M. Iida, A. Oshima, Y. Tabata, M. Washio, Eur. Polym. J. 40, 775-783 (2004).

8) J.Y. Li, K. Sato, S. Ichizuri, S. Asano, S. Ikeda, M. Iida, A. Oshima, Y. Tabata, M. Washio, Eur. Polym. J. 41, 547-555 (2005).

9) S. Asano, F. Mutou, S. Ichizuri, J.Y. Li, T. Miura, A. Oshima, Y. Katsumura, M. Washio, Nucl. Instr. and Meth. in Phys. Res. B 236, 437-442 (2005).

10) J.Y. Li, et al, J. Appl. Polym. Sci. 101, 3587-3599 (2006).

11) J.Y. Li, A. Matsuura, T. Kakigi, T. Miura, A. Oshima, M. Washio, J. Power Sources 161, 99-105 (2006).

12) A. Matsuura, T. Kakigi, Y. Sato, K. Fujii, N. Mitani, J.Y. Li, A. Oshima, M. Washio, Macromol. Symp. 249-250, 221-227 (2007).

13) Y. Sato, et al, Nucl. Instr. and Meth. in Phys. Res. B, Submitted.

14) D. Chu, R. Jiang, J. Power Sources 80, 226-234 (1999). 